\title{
SPECIFICS OF MODELING OF THE NATIONAL CHARACTER IN THE WORKS BY LES MARTOVYCH
}

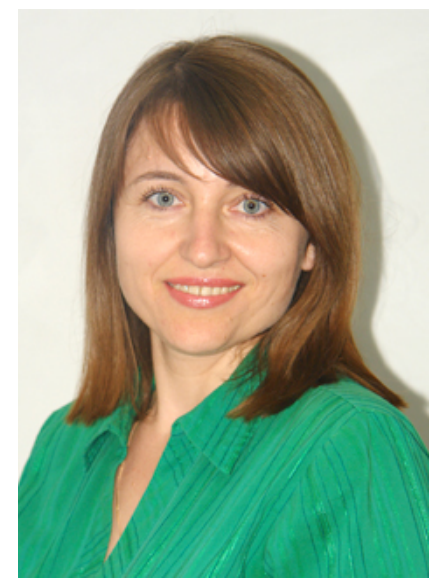

(C) Valentyna Myroniuk, $\mathrm{PhD}$, Associate Professor, Associate Professor of the Department of Ukrainian literature of the Faculty of History and Philology, CVUS «Academician Stepan Demianchuk International University of Economics and Humanities», vul. Acad. S. Demianchuk, 4, Rivne, Ukraine.

The article examines the questions of a national character, extending the idea of national identity of psychology in works of Les Martovych, due to both personalindividual qualities of character of the writer and characters, their attitude and perception of the world and socio-political conditions of life. The dominant worldview of the writer and the concept of man and the world are determined.

Based on the analysis of the works are studied the archetypes of truth, goodness and beauty, and also of land, nature and freedom, which are characteristic for the Ukrainian national character. It is emphasized that the main characters of Les Martovych are quite self-sufficient characters with their own views on life, philosophy of life and beliefs.

Key words: national character, psychology, ideology, national identity, ethical and moral values

The forming and becoming of the creative Les Martovych's method is deeply rooted in people's life. This gives the opportunity to objectively explore the issue of national aesthetic traditions, psychology and philosophy, in particular the national character, which greatly expands the idea of the national identity of the psychology of the artist's works.

His characters are colorful national types with such character traits as diligence, conscientiousness, optimism, warmth, endurance, reliability. The expression characteristic of the Ukrainian national character archetypes of truth, goodness, beauty, and the archetypes of the earth, nature, freedom can be found in the works of 
the writer. Today, in independent Ukraine, there is an urgent problem to consider image features of the national character of Ukrainians in the works of Les Martovych.

This problem is still insufficiently developed in the Ukrainian ethnological and literary studies and only some of its aspects became subject of attention of $\mathrm{M}$. Nabok according to the Ukrainian national dumas, L. Gorbolis in the researching the works of G. Kvitka-Osnovianenko, V. Pratsiovytyi «Ukrainian national character in drama of Mykola Kulish», O. Lavryk in the works of G. Khotkevych, V. Narivska "The national character in the Ukrainian prose of the 50-70-ies of XX century». Some attempts of studying the national character in the works of Les Martovych can be found in the works of M. Zerov, O. Zasenko, O. Gnidan, O. Biletskyi, A. Muzychko, F. Pogrebennyk, R. Pikhmanets. However, despite the diverse range of literary-critical reflections in contemporary literary studies, the questions of a national character in the works of Les Martovych remain on the periphery of scientific research.

The article aim is to find out the particular reflection of national character of Ukrainians in the works of Les Martovych as one of the problems of formation the national fundamental bases of the modern Ukrainian literature.

Les Martovych is a writer of high aesthetic culture, of the breadth of the sociopolitical outlook, he believed in a democratic and free Ukrainian state, in which the rightful owner is «a decent man, one that works, not a thief and not a robber» (Мартович, 1976: 23). The greatness of the creativity of the novelist is that he managed to combine national with panhuman, that is, love to the Ukrainian man with a modern outlook and the means of artistic effect.

It is worth to note that artistic thinking, and therefore, the principles of creation the national characters in the works of L. Martovych are closely associated with the emotionality of Ukrainian peasants, peculiarities of its attitude and the world perception, and also socio-political conditions of life. Thanks to the deepening into the peasant's soul, the writer revealed the psychology of the folk spirit in his works. He carefully and sensitively listened to it what was the most significant and impressive.

Early artist's works prepared the ground for further creative searches of the writer's delineation of national character. Literary critics, in particular F. Pohrebennyk, believe that Les Martovych reproduced Ukrainian character, gave a national flavor through the reflection customs, way of life, folklore, landscape and portrait drawings. 
Even in his early works the artist acts above all as a master of social paintings from the life of peasants of Pokuttia as a good expert in psychology of the human's work. The writer has shown that the successes and failures of some individuals, their grief very often were conditioned by the circumstances of political and economic life. The person showed their character under the influence of the social and political dramas. The task of the writer was to provide new types of people, to approximate the desired future. He didn't paint a perfect world, but made it beautiful and interesting. The Martovych taught us to love people for who they are» (Франко, 1981: 118).

The central problem of the writer's works is the problem of the rise of social and national consciousness of the masses, their cohesion in the fight against the Hungarian enslavement, and that was one of the main source of creation of the bright distinctive national character, and for the literature it was the key of forming the principles of the national fundamental basis of the study of his life and creativity. The Martovych is one of the best in our literature experts of everyday life and the psychology of the worker-peasant. His work covered a wide Western Ukrainian ethnographic territory. If in the early stories, particularly in «Muzhytski smetri», we are talking about characteristic features of life of the population of Pokuttia, in later works, especially in the story «Zabobon», the writer recreates the picture of life of the people of Rava-Russian province (now Lviv region), where for many years he lived and worked (Погребенник, 1971: 9).

In his relation to the village writer, as his brothers Vasyl Stefanik and Marko Cheremshyna, was uncompromising: with all his heart loving those who "pours his sweat and blood, who is oppressed by the shackles» (Франко, 1981: 118), raising his flaming word to protect them, Martovych mercilessly ridiculed individualism of a certain part of the peasantry, their slavish obedience and passivity. Pohrebennyk noted: «He was trying to awake in them a sense of human dignity, instilled in their hearts faith in their own strength. That's why there is so much warmth in his works to the man-worker who is looking for a way to throw out the chains of social and spiritual enslavement, here is a strong condemnation of those who humbly bends his back» (Погребенник, 1971: 100). The village for Martovych is both and painful wound, and the bright hope («Myzhytska smert», «Hytryi Panko», «Smertelna sprava», «Viit», «Zabobon»).

In the book «Nechytalnyk» Martovych acts first of all as a great connoisseur of the psychology of working people and their character, as a master of social paintings from the life of Pokuttia of the peasantry. The works included into this book, were very similar to the subject and to the use of artistic means, but at the same time, they 
were different in the nature of humor, gosselins irony, satire. Along with objectiverespawn style of writing all the more clearly felt the tilt of the writer to be expressive dialogue speech, to drama genre. For example, the story, «Za mezhu», «Os’ posy moie!», «Zle dilo», that are illuminating various aspects of people's life, expand the themes from the early works of the writer.

In the center of the conflict of the stories are new socio-moral conflicts, dictated by the time, and those «eternal» problems that affect the very meaning of human existence, the man's relationship with society.

In this case, it is interesting to analyze the story «Za mezhu». The main attention is concentrated on the solving conflict between Ivanykha and Gryts, who quarreled and fought. Gryts beat Ivanykha «on the head, hands, feet»; she sued him in court for «defamation». But the court did not help, because the witness of Ivanycha, as it turned out, did not see the Gryts's lynching. So, not finding her right, Ivanykha went home with nothing, and Gryts came from the water dry, plucking a bit of fear.

In the centre of this conflict is the struggle for the strip of land. Ivanykha thinks that the border that Gryts wanted to get, was her own. Gryts is strongly against of it, proving his right to the border. The economical impoverishment and destruction of the Galician village led to the big and small dramas of social and domestic nature, to the strengthen of the egoistic proprietary sentiment among the backward part of the masses. «It has long been widely: nobody abroad did not care, and now it became tightly, too tightly» says one of the characters of the story «Za mezhu». It came down to the fact that the narrow strip of the land was the reason of the fight. " One day the murder will happen on that border. Or, he says, he will kill me or I will kill him» So, Martovych approached to the subject of land, focusing on those socio-economic processes, that took place in the Galician countryside.

However, Les Martovych created a bright domestic picture, created three peasant's types: Ivanykha that reminds a person from the village who likes to quarrel, tricky Gryts, who nimbly gets out from the punishment for beating his neighbor, and the unnamed witness who is very talkative and naive. He expresses, by his mouth, the thoughts of people, whom «now is tighty, too tighty» to live as the worker-farmers, he defends the opinion about the necessity of consolidation among the peasants, encourages to respect others work. «The author deliberately emphasixed here on the moral and ethical aspects, he represented the social conflict as a comic color household perspective» (Погребенник, 1971: 101). 
A deep and holistic view on the dual nature of man and the world was characteristically for the philosophical outlook of the writer. Man leads a constant struggle of their feelings, where internal and external is combined.

Exploring the inner world of man, the problems of the individual, the writer often refers to the folklore. The genre of satirical tales was originated on the basis of the development of literary and folklore genres. The majority of the main heroes in many works of the author are popular narrators on whose behalf the story is told.

The Martovych was a great artist in reproducing everyday scenes from people's lives in the spirit of folk humor. They amaze by the great knowledge of the customs, behavior, and psyche of the working man.

The main feature of the humor and satire of Martovych is their genuinely national character, a great variety of art tools and techniques. Nationality of the humor and satire lies in the fact that he opened people's views on certain social phenomena, the events of family life.

Les Martovych very often turned to the genre of fairy tales. R. Pikhmanets notes: «The Tale has a strong power of generalization. It has been long distinguished into certain groups of motives or «microthemes», which in any case can vary, impose, and are originally combined, and they create the rich texture of the cast-art complex. Regardless how we call the minimum units, they are directed to the formation of a «community» of certain invariants and typological formulas» (Піхманець, 2012: 497). For example, in the story «Ivan Rulo» of Les Martovych, the unconscious peasants were ridiculed because of selling themselves to the lords, serving them and betraying the interest of their nation.The ideological direction of the exposure of the deceit, treachery and betrayal of national interests and with its artistic means the satirical tale «Ivan Rylo» by Martovych is close to the satirical tales of Ivan Franko «Svynia» (1890). The main character in Martovych work Ivan Rylo was a werewolf, who could transform into any animal, also had a supernatural ability « to jump in the people» infecting them by «low» instincts of their psyche. «So here is the man, and Ivan Rylo is around him. Suddenly Ivan jumped, and only the man left, and Ivan Rylo has already gone, so, you see, he jumped into a man. You cannot recognize it just looking at the man: the man was the same, but talk to him and then you see that Ivan Rylo is inside of him, now he will make him a pig, or a rabbit, or another beast» (Мартович, 1976: 48). People that are infected with the psychology of the werewolf is still increasing and forming a special socio-psychological type. 
A fairy tale for adults «Strybozhyi darunok» is also written in the genre of satirical prose, in which Les Martovych proved himself as «extremely close observer of the Galician people» (Франко, 1981). The passion of the writer due to the fairy tale form was caused by hi, interest in spoken word poetry as an important source of knowledge of people's life, that was inoculated to him in his childhood. The author's appeal to the genre of literary fairy tales was caused by a number of circumstances, above all is the content of the concept of personality, shaped by life experience and the development of cultural and literary traditions, which occupies an important place in the mythological beginning.

So, describing his characters, the writer could deeply see their inner world, and this has helped in revealing the features of Ukrainian national character. The writer has recreated Ukrainian character, gave a national flavor through reflection customs, way of life, folklore, landscape and portrait drawings. In the works of the artist were found expression of archetypes of truth, goodness and beauty, and the archetypes of the earth, nature and freedom that is characteristic of the Ukrainian national character. His characters are colorful national types, with such traits as emotionality, industriousness, warmth, honesty, reliability, modesty.

The problem raised in the article, without a doubt, is relevant, and, therefore, promising. Therefore, it requires further studies involving a wider theoretical material.

\section{REFERENCES}

Горак, Р. (1990). Лесь Мартович. Київ: Молодь.

Денисюк, I. О. (1981). Розвиток украӥнської малої прози XIX-поч. ХХ ст. Київ: Вища шк.

Зеров, М. (1990). Твори. Т.2.

Зеров, М. (2003). Українське письменство. Київ: Видавницво Соломії Павличко «Основи».

Мартович, Л. (1976). Вибрані твори. Ужгород: Карпати.

Піхманець, Р. В. (2012). Із покутської книги бутя. Засади творчого мислення Василя Стефаника, Марка Черемшини і Леся Мартовича. Київ:Темпора. 
Valentyna Myroniuk SPECIFICS OF MODELING OF THE NATIONAL CHARACTER IN THE WORKS BY LES MARTOVYCH Accents and Paradoxes of Modern Philology, Issue 1(1) 2017, pp. 59-65

Погребенник, Ф. (1971). Лесь Мартович. Життя і творчість. Київ: Дніпро. Франко, І. Я. (1981). Зібрання творів. Т. 31. Київ.

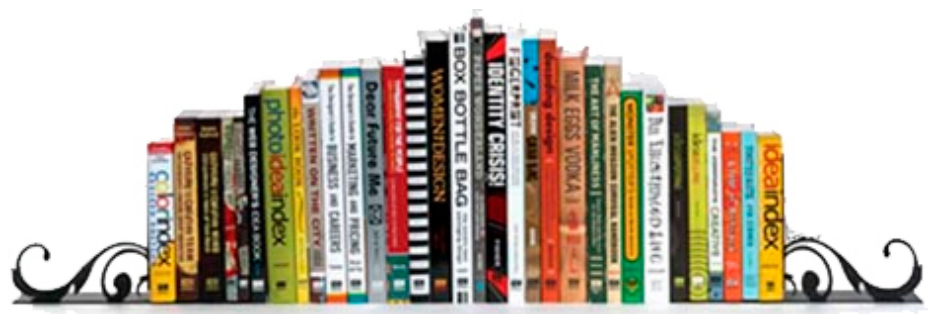

